Zeszyty Naukowe Szkoły Głównej Gospodarstwa Wiejskiego w Warszawie Problemy Rolnictwa Światowego tom 17 (XXXII), zeszyt 2, 2017: 256-266

DOI: $10.22630 /$ PRS.2017.17.2.44

Agnieszka Tarnowska ${ }^{1}$

Uniwersytet Ekonomiczny we Wrocławiu

\title{
Kierunki rozwoju przemysłu spożywczego w Polsce i w Hiszpanii - analiza porównawcza
}

\section{Directions of Food Industry Development in Poland and in Spain - Comparative Analysis}

\begin{abstract}
Synopsis. Przemysł spożywczy jest ważnym sektorem gospodarki Polski i Hiszpanii, dwóch krajów UE o najbardziej zbliżonych potencjałach produkcyjnych ziemi i pracy. Celem artykułu było porównanie kierunków i tempa rozwoju tego przemysłu na tle UE. Hiszpania po przystappieniu do Wspólnoty bardzo się rozwinęła gospodarczo i infrastrukturalnie. Jednak w ostatnich latach mocno odczuła skutki globalnego kryzysu gospodarczego. Wpłynął on również na przemysł spożywczy, który jest relatywnie mało podatny na wahania koniunktury. Dla Polski jest to pouczające doświadczenie, gdyż po akcesji do UE rozwija się w podobny sposób. Analiza wyników działalności polskiego przemysłu spożywczego świadczy o szybkim jego wzroście i możliwościach konkurowania z Hiszpanią w przyszłości głównie w branży mleczarskiej i paszowej.
\end{abstract}

Słowa kluczowe: przemysł spożywczy, Polska, Hiszpania

\begin{abstract}
The food industry is an important economic sector in Poland and Spain, two EU countries with the most similar production and land-use potential. The aim of the article was to compare the directions and pace of development of this industry against the EU. Spain, after its accession to the Community, has developed economically and infrastructurally. In recent years, however, the effects of the global economic crisis have been strongly affected Spain economy. It also affected the food industry, which is relatively less susceptible to fluctuations in economic conditions. For Poland this is an instructive experience, because after its accession to the EU it develops in a similar way. The analysis of activity results of the Polish food industry is evidence of its rapid growth and its ability to compete with Spain in the future mainly in the dairy and feed industry.
\end{abstract}

Key words: food industry, Poland, Spain

\section{Wprowadzenie}

Przemysł spożywczy wraz z rolnictwem stanowią filar unijnej gospodarki, a produkcja żywności wysokiej jakości jest ważnym celem polityki żywnościowej Wspólnoty. Przemysł artykułów żywnościowych w Unii Europejskiej rozwija się w podobnym tempie do całej gospodarki. Jest on mało podatny na wahania koniunktury, ponieważ dostarcza dóbr podstawowych, tj. żywności, charakteryzującej się małą elastycznością popytu. Przemysł spożywczy nie jest zaliczany do tzw. branż dynamicznych, ale mimo postępującej restrukturyzacji przemysłu, nie traci na znaczeniu (Fierla, 2011). Jego rozwój podyktowany jest rosnącym popytem na żywność, i rosnącym eksportem artykułów spożywczych na

\footnotetext{
${ }^{1}$ dr inż., Katedra Zarządzania i Gospodarki Żywnościowej, Wydział Inżynieryjno-Ekonomiczny, Uniwersytet Ekonomiczny we Wrocławiu, ul. Komandorska 118-120, 53-345 Wrocław,

e-mail: agnieszka.tarnowska@ue.wroc.pl
} 
rynki pozaunijne. Przemysł spożywczy to najbardziej różnorodny i największy sektor przetwórstwa przemysłowego w Unii Europejskiej pod względem wielkości obrotów, zatrudnienia i wartości dodanej. Wykorzystuje około 70\% surowców rolnych produkowanych we Wspólnocie. Generuje miejsca pracy zarówno na terenach wiejskich, jak też w miastach (Promoting..., 2014).

Hiszpania i Polska (po Niemczech, Francji, Włoszech i Wielkiej Brytanii) należą do największych producentów żywności w Unii Europejskiej. Polska jest liderem sektora rolno-spożywczego wśród nowych państw członkowskich (UE-13). Zdaniem Wysokińskiej (2011) ten sektor bazujący na produkcji ekologicznej i zdrowej żywności może stać się potencjalnym katalizatorem rozwoju konkurencyjności polskiej gospodarki na globalnym rynku. Polska stała się członkiem Wspólnoty w 2004 roku, Hiszpania - w 1986. To kraje o zbliżonych potencjałach produkcyjnych ziemi i pracy, ale i ogromne rynki zbytu produktów spożywczych. Obszar Hiszpanii sięgający 506 tys. $\mathrm{km}^{2}$ jest o $62 \%$ większy od Polski. Udział użytków rolnych, będących bazą surowcową dla przemysłu spożywczego, w obu krajach wynosi po $46 \%$ powierzchni ogólnej. Liczba ludności, stanowiącej potencjał produkcyjny i popytowy, wynosząca w Hiszpanii $46 \mathrm{mln}$, a w Polsce $38 \mathrm{mln}$, plasuje te kraje odpowiednio na 5. i 6. miejscu we Wspólnocie. W Hiszpanii niższa niż w Polsce jest gęstość zaludnienia. W 2016 roku na $1 \mathrm{~km}^{2}$ przypadały 92 osoby wobec $123 \mathrm{w}$ Polsce. Mediana wieku mieszkańców Hiszpanii wynosiła wówczas 42,8 lat, w Polsce - 39,9. Hiszpańskie społeczeństwo boryka się z wyższym niż w Polsce wskaźnikiem obciążenia demograficznego $(51,2 \%$ vs. $44,9 \%)$ oraz bardzo wysoką stopą bezrobocia $(19,6 \%$ vs. $6,2 \%)$ (Eurostat). Odsetek osób poszukujących pracy wśród czynnych zawodowo oscylował w granicach $19-20 \%$ w obu krajach w momencie ich przystapienia do UE. Wartość rzeczowego majątku trwałego Hiszpanii szacowana jest na pond 5 bln USD, co daje jej 12 miejsce na świecie. Polska, z majątkiem o połowę mniejszym, zajmuje miejsce 21. Jednakże spośród 32 krajów analizowanych w raporcie Global Built Asset Wealth Index (2015) Hiszpania w latach 2012-2014 odnotowała największy spadek wartości materialnych środków trwałych, tj. o 3,8\%. W 2016 roku nakłady brutto na środki trwałe zmniejszyły się w porównaniu z rokiem 2005 o 20,7\%, podczas gdy w Polsce wzrosły wówczas o $65,2 \%$ (Eurostat).

Hiszpania i Polska przed wstapieniem do Wspólnoty, należały do krajów o niskim poziomie rozwoju gospodarczego. Po trudnym okresie dostosowania do warunków działania $\mathrm{w}$ ramach struktur unijnych oba państwa odczuły wyraźną poprawę sytuacji społecznej i ekonomicznej. Stawiano je za przykład krajów, które dzięki akcesji do UE i jej polityce strukturalnej zdołały zwiększyć konkurencyjność na europejskim rynku wykorzystując wspaniale szanse na rozwój. Hiszpania od roku 1989 otrzymała największe środki unijne w zakresie pomocy strukturalnej na większości swojego terytorium (Piecuch 2017). Obecnie Hiszpania będąca we Wspólnocie 18 lat dłużej od Polski jest krajem od niej zamożniejszym, lepiej rozwiniętym gospodarczo i infrastrukturalnie. Oba kraje różnią się klimatem i ukształtowaniem terenu. Warunki klimatyczne zdecydowanie sprzyjają Hiszpanii, ukształtowanie terenu korzystniejsze jest w Polsce. Oba kraje maja jednak dostęp do morza.

Wartość hiszpańskiego PKB w 2016 roku szacowano na 1114 mld euro, w Polsce było o $62 \%$ niższe. W przeliczeniu na mieszkańca dysproporcje w poziomie życia między oboma krajami są mniejsze, zwłaszcza wyrażanego w parytecie siły nabywczej. Na 1 mieszkańca w Polsce przypadało 11 tys. euro (20 tys. PPS), a w Hiszpanii 24 tys. euro (26 tys. PPS). Ostatni kryzys gospodarczy bardzo silnie negatywnie odbił się na rozwoju 
hiszpańskiej gospodarki. Roczna dynamika PKB w latach 2009-2013 była ujemna. W roku 2016 w porównaniu do 2010 roku wyniosła zaledwie $2,0 \%$. W Polsce w analogicznym okresie odnotowano wzrost o $19,6 \%$. Polska wciąż należy do krajów rozwijających się, w których roczna dynamika PKB przyjmuje zazwyczaj wartości z przedziału 5-15\%, w krajach rozwiniętych to 2-3\% (Szwacka-Mokrzycka, 2015).

Przykład Hiszpanii stanowi dla Polski cenne źródło wiedzy o zmianach gospodarczych zachodzących na różnych etapach funkcjonowania w UE. Hiszpania obecnie wychodzi $\mathrm{z}$ recesji, która mocno odbiła się na jej gospodarce, $\mathrm{w}$ tym także na przemyśle spożywczym. Czy zahamowanie w hiszpańskiej gospodarce może być dla Polski szansą na większą ekspansję na unijne rynki produktów spożywczych? Czy Polska może wykorzystać doświadczenia Hiszpanii i czy jest w stanie z nią konkurować? Niniejszy artykuł ma dać odpowiedzi na te pytania ograniczając się wszakże do mezo skali, tj. rozwoju przemysłu spożywczego stanowiącego ważną gałąz gospodarki obu krajów.

W literaturze przedmiotu nie spotyka się wielu publikacji porównujących funkcjonowanie gospodarek obu omawianych państw, a już na pewno brak pozycji, które w sposób kompleksowy opisywałyby poszczególne branże przemysłu spożywczego w obu krajach. Częściej polscy autorzy interesują się Hiszpanią, niż Hiszpanie Polską. Na uwage zasługuje monografia Rakowskiego (2017), w której skupiono uwage na rozwoju gospodarczym wyłącznie Polski i Hiszpanii. Jest natomiast sporo publikacji opisujących pozycję polskiego sektora rolno-spożywczego na tle krajów UE (Szwacka-Mokrzycka, 2009; Urban, Szczepaniak, Mroczek, 2010; Pawlak, 2013; Poczta, Beba, 2014; WrzesińskaKowal, Drabczyk, 2014; Mroczek, 2014, 2015).

\section{Cel, materiał i metody}

Głównym celem niniejszej publikacji jest porównanie kierunków i tempa rozwoju polskiego i hiszpańskiego przemysłu spożywczego po okresie światowego kryzysu gospodarczego, tj. w latach 2010-2016. W zasadniczej części opracowania, z uwagi na brak bardziej aktualnych danych, analiza została zakończona w roku 2015. Przemysł spożywczy tworzą trzy działy NACE Rev. 2 (2008): C10 - produkcja artykułów spożywczych, C11 produkcja napojów oraz C12 - produkcja wyrobów tytoniowych (Poczta, Beba, 2014). W opracowaniu skupiono się przede wszystkim na produkcji żywności. Dział C10 jest bowiem bardzo różnorodny i rozwija się dużo szybciej niż dwa pozostałe działy przetwórstwa rolno-spożywczego. Podmiotem badań były dwa kraje - Polska i Hiszpania, a them odniesienia UE-28.

Zdaniem Kołodki (2008, s. 318) „porównanie jest niezwykle cennym instrumentem badawczym, gdyż spośród całej wiązki uwarunkowań wzrostu i rozwoju pozwala nam wydobyć tło krytyczne, którego obecność może zadecydować o zaistnieniu zjawiska lub przetoczeniu się procesu". Porównując rozwój gospodarczy Polski i Hiszpanii posłużono się syntetycznym miernikiem, jakim jest PKB. Następnie badano udział wartości dodanej brutto przetwórstwa przemysłowego jako całości i przemysłu spożywczego w PKB. Za pomocą wskaźników dynamiki i struktury analizowano znaczenie działu $10 \mathrm{w}$ przemyśle spożywczym obu krajów. Najważniejszymi jednak czynnikami, które przyjęto do badania kierunków rozwoju poszczególnych branż (grup działu 10) były:

- Liczba przedsiębiorstw; 
- Wartość produkcji;

- Nadwyżka operacyjna brutto;

- Inwestycje brutto w dobra materialne,

- Liczba pracujących,

- Wydajność pracy.

Opracowanie ma charakter teoretyczno-empiryczny. Oparte zostało na krajowej i międzynarodowej literaturze przedmiotu. Dane statystyczne pozyskano w większości z publikacji i baz danych Eurostat i FAOSTAT.

\section{Baza surowcowa przemysłu spożywczego i jego znaczenie dla gospodarek Polski i Hiszpanii}

Użytki rolne w 2013 roku zajmowały w Hiszpanii 23,3 mln ha, w Polsce - o 62\% mniej. W strukturze tzw. typowych UR w obu krajach dominowały grunty orne (rys. 1). W Polsce zajmowały $76 \%$ UR, w Hiszpanii - nieco ponad 46\%. Zarówno w Polsce, jak i w Hiszpanii na gruntach ornych uprawia się przede wszystkim zboża. W Hiszpanii dużą powierzchnię zajmują także uprawy warzyw (pomidorów i papryki), a także ziemniaków i buraków cukrowych (Eurostat). Hiszpania jest po Włoszech drugim największym producentem pomidorów w Unii Europejskiej. W latach 2010-2012 jej udział w wielkości produkcji tych warzyw we Wspólnocie wyniósł 25,3\% (Tarnowska, 2014). Hiszpania jest światowym liderem $\mathrm{w}$ produkcji mandarynek, pomarańczy i cytryn. Na wysoki udział upraw trwałych w strukturze UR wpływa również powszechna uprawa winogron i oliwek. Górzyste ukształtowanie terenu sprawia, że na Półwyspie Iberyjskim powszechny jest wypas owiec, kóz i bydła. Łąki i pastwiska zajmują tam ponad 35\% powierzchni UR.

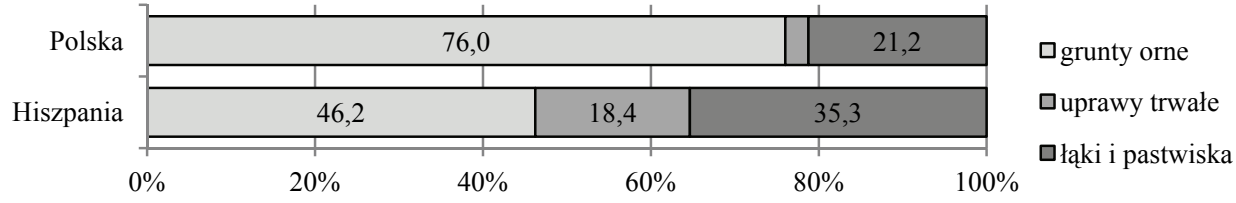

Rys. 1. Struktura typowych użytków rolnych w Polsce i w Hiszpanii w 2013 roku

Fig. 1. Structure of typical agricultural land in Poland and in Spain in 2013

Źródło: opracowanie własne na podstawie Eurostat.

Baza surowcowa przemysłu rolno-spożywczego jest bardziej urozmaicona w Hiszpanii niż w Polsce. Ciepły klimat tego kraju, z jednej strony sprzyja prowadzeniu bardzo urozmaiconej produkcji roślinnej, z drugiej jednak sprawia, że produkcja ta wymaga większych nakładów na systemy nawadniające.

Zarówno w Hiszpanii, jak też w Polsce zdecydowana większość surowców dla przemysłu spożywczego pochodzi od rodzimych producentów. Przemysł spożywczy obu tych krajów jest dobrze rozwinięty i na tle UE ma duże znaczenie dla obu gospodarek, w odróżnieniu od całości przetwórstwa przemysłowego (sekcja C). Znaczenie to można określić za pomocą udziału wartości dodanej brutto tej sekcji i działów C10-C12 w tworzeniu PKB (rys. 2). W latach 2010-2015 omawiany wskaźnik dla sekcji C wzrósł w UE z $13,82 \%$ do $14,24 \%$. W Hiszpanii jego wartości kształtowały się poniżej średniej dla 
Wspólnoty, choć odnotowano wzrost o 0,75 pp. Przetwórstwo przemysłowe w tym kraju nie ma już tak dużego wpływu na gospodarkę, jak np. w Polsce, gdzie zarówno jego udział
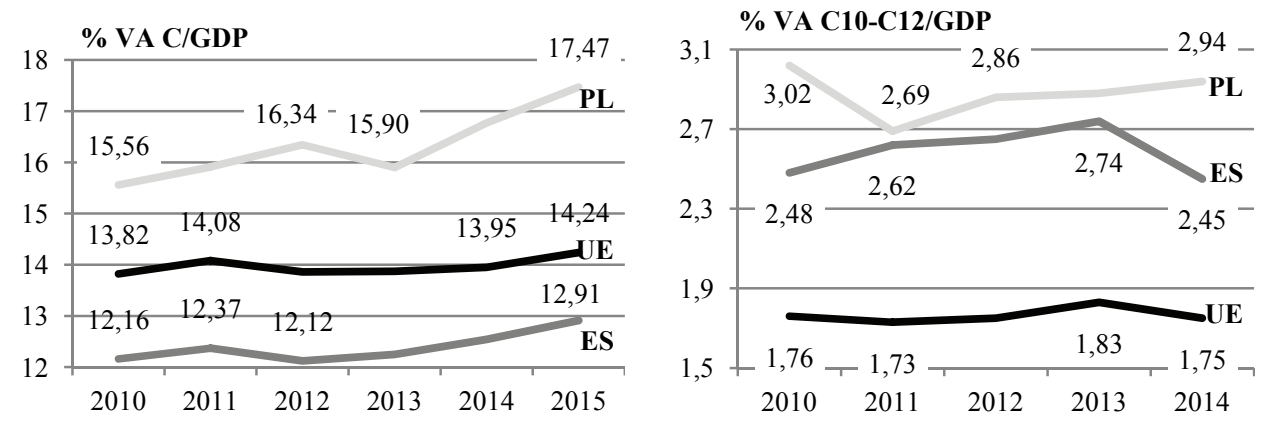

w PKB (17,5\%), jak też dynamika są dużo wyższe, zwłaszcza po 2013 roku.

Rys. 2. Udział wartości dodanej (VA) przetwórstwa (sekcja C) i działów przemysłu spożywczego (działy C10C12) w wartości PKB Polski i Hiszpanii na tle UE (w \%)

Fig. 2. The share of value added (VA) in processing (section $\mathrm{C}$ ) and food industry divisions (C10-C12 divisions) in the value of GDP of Poland and Spain against the EU (in\%)

Źródło: opracowanie własne na podstawie FAOSTAT.

Polskę i Hiszpanię wyróżnia na tle ogółu krajów UE stosunkowo wysoki udział wartości dodanej brutto przemysłu spożywczego w PKB. W Polsce ten przemysł wniósł do PKB blisko 3\% wartości dodanej w 2014 roku. W Hiszpanii niewiele mniej, bo około $2,5 \%$. Warto zaznaczyć, że w strukturze wartości przetwórstwa przemysłowego ogółem udziały poszczególnych działów przemysłu spożywczego są zdecydowanie różne. W 2015 roku w dziale C10 (produkcja żywności) wytwarzano 19,2\% wartości produkcji całej sekcji C w Hiszpanii, 16,3\% - w Polsce, 13,0\% - w UE. Produkcja działu C11 (produkcja napojów) stanowiła odpowiednio 3,5\%, 2,5\%, 2,2\% wartości przetwórstwa przemysłowego, a dział $\mathrm{C} 12$ odpowiadał zaledwie kolejno za $0,2 \%, 1,0 \%, 0,6 \%$ wartości tej produkcji (FAOSTAT).

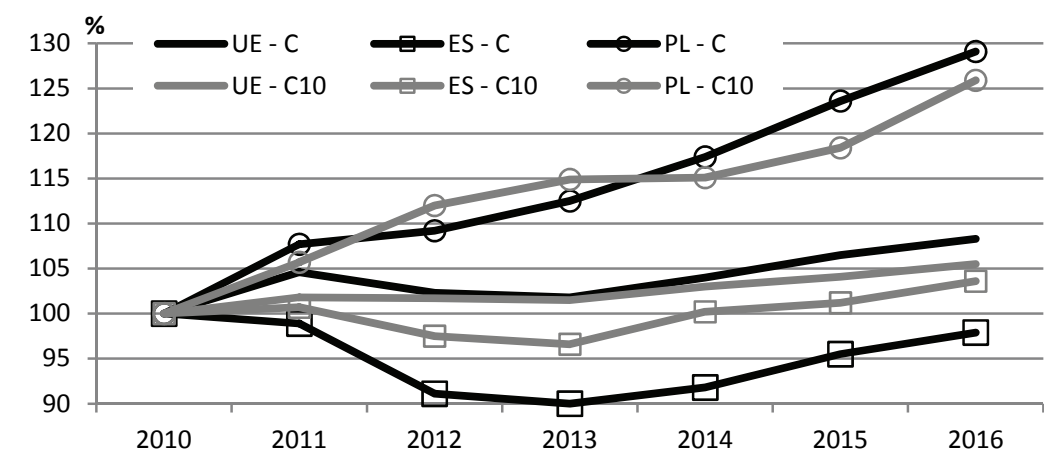

Rys. 3. Dynamika wolumenu produkcji w przetwórstwie przemysłowym ogółem (sekcja C) oraz produkcji artykułów spożywczych (dział C10) w Polsce i w Hiszpanii na tle UE (\%, 2010=100)

Fig. 3. Production value dynamics in manufacturing (section C) and food production (division C10) in Poland and Spain against $\mathrm{EU}(\%, 2010=100)$

Źródło: opracowanie własne na podstawie Eurostat. 
Ponadprzeciętny udział produkcji żywności w wartości przetwórstwa przemysłowego świadczy o dużym znaczeniu tego działu dla gospodarek obu krajów. Warto zatem głębiej przeanalizować zmiany w nim zachodzące, zwłaszcza, że jest to dział bardzo różnorodny. Dalsza analiza zostanie więc ograniczona tylko do działu C10, ponieważ zachodzące w nim zmiany są bardzo dynamiczne, zwłaszcza w Polsce (rys. 3).

W latach 2010-2016 przetwórstwo przemysłowe (sekcja C) w UE rozwijało się w umiarkowanym tempie wynoszącym średnio $4,6 \%$ rocznie (rys. 3). Wyraźne ożywienie i wzrost wolumenu produkcji obserwowane były od 2014 roku. W ten trend wpisywała się również produkcja żywności, której wielkość rosła średnio o $2,9 \%$ rocznie. Na tym tle mało korzystnie przedstawiała się sytuacja hiszpańskiego przetwórstwa odnotowującego spadek produkcji średnio o 5,8\%. W produkcji żywności po okresie recesji trwającym do 2013 roku zdołano odbudować wielkość produkcji i średnioroczny wskaźnik dynamiki wyniósł ostatecznie $0,0 \%$. Zupełnie inaczej przedstawiała się kondycja polskiego przetwórstwa, w którym z roku na rok utrzymywał się niemal proporcjonalny wzrost produkcji (średnio o 16,6\% rocznie). Dynamika produkcji żywności była tylko nieco mniejsza (15,3\%).

\section{Rozwój branżowy w produkcji artykułów spożywczych}

Produkcja artykułów spożywczych to dział bardzo różnorodny. Według klasyfikacji NACE składa się na niego dziewięć grup. Największy udział, zarówno w wartości produkcji, jak też $\mathrm{w}$ zatrudnieniu i w Polsce, i w Hiszpanii, ma grupa C101 - Mięso i wyroby z mięsa, zakonserwowane (rys. 4). W 2015 roku przetwórstwem mięsa zajmowały się w Hiszpanii 3484 zakłady, w Polsce - o 21,6\% mniej. Zarówno w Hiszpanii, jak też w Polsce liczba tych zakładów zmniejszyła się - w porównaniu z 2010 rokiem odpowiednio o $13,7 \%$ i 4,4\% (rys. 5). Wartość produkcji wyniosła w Hiszpanii 20,0 mld euro i zwiększyła się o $6,9 \%$. W Polsce ukształtowała się na poziomie 13,8 mld euro, a jej wzrost osiagnął $39,0 \%$. Polski przemysł mięsny wypracował 941 mln euro nadwyżki operacyjnej brutto i była ona o $107,5 \%$ wyższa niż w roku bazowym 2010. W Hiszpanii przyrost nadwyżki sięgał 41,2\%, ale jej wartość była ponad dwukrotnie wyższa niż w Polsce. Nadwyżka operacyjna brutto stanowi fundusz rozwojowy przedsiębiorstwa pozwalający m.in. finansować inwestycje. W hiszpańskim przemyśle mięsnym w 2015 roku 40,5\% tej nadwyżki zainwestowano w dobra materialne i była to kwota o $43,1 \%$ wyższa niż w roku bazowym. W Polsce na inwestycje przeznaczono 53,5\% nadwyżki, tj. o 45,7\% więcej niż w roku 2010. Rozwój branży mięsnej w Hiszpanii był wolniejszy i połączony ze wzrostem zatrudnienia do 85,0 tys. osób, tj. o $1,9 \%$. W porównaniu z Polską zatrudnienie $\mathrm{w}$ hiszpańskich zakładach mięsnych było niższe o 33,8 tys. osób. W Polsce dał się zaobserwować spadek liczby pracujących o $3,4 \%$, ale jest on w zasadzie proporcjonalny do redukcji liczby zakładów. Na rynku pozostają te najlepsze, generujące wysokie zyski i stawiające na wyższą wydajność pracy. Niestety $\mathrm{w}$ porównaniu $\mathrm{z}$ pracownikami hiszpańskimi wydajność pracy $\mathrm{w}$ polskich zakładach jest dużo niższa - mierzona wielkością obrotu na pracującego wynosiła bowiem w Hiszpanii 270,7 tys. euro, a w Polsce 121,8. Pozytywnie należy ocenić jednak fakt szybszego wzrostu tej wydajności w Polsce o $34,1 \%$ wobec $17,6 \%$ w Hiszpanii.

W Polsce drugim pod względem wartości produkcji jest przemysł mleczarski (grupa C105). Reprezentuje go 521 przedsiębiorstw zatrudniających 38,9 tys. osób, tj. kolejno o $21,4 \%$ i $6,0 \%$ mniej niż w 2010 roku. W porównaniu z Hiszpanią są to zakłady duże, 
liczące średnio po 75 osób (w Hiszpanii - 15). Niezależnie od tego wydajność pracy w hiszpańskich mleczarniach wynosząca 392,2 tys. euro jest niemal dwukrotnie wyższa niż w Polsce i w porównaniu z rokiem 2010 wzrosła o 13,8\% wobec 32,0\% wzrostu w Polsce. Wyższa niż w Polsce jest również wartość produkcji tej branży w Hiszpanii $(8,0$ mld euro wobec 6,3$)$. Zakładów produkujących wyroby mleczarskie jest w tym kraju 2,8 razy więcej niż w Polsce i od 2010 jeszcze ich przybyło o $1 \%$ przy $17,1 \%$ redukcji zatrudnienia. Kondycja tej branży nie jest stabilna. Wprawdzie wartość produkcji w Polsce wzrosła o $11,2 \%$, ale nadwyżka operacyjna brutto w 2015 była o 29,5\% niższa niż w 2010 roku. Nie zahamowało to inwestycji. Przeznaczono na nie $67,1 \%$ tej nadwyżki, tj. kwotę o $27,5 \%$ wyższą niż pięć lat wcześniej. W Hiszpanii wyniki finansowe mleczarni świadczą o pogarszającej się sytuacji tej branży. Obniżyły się: wartość produkcji (o 6,7\%), nadwyżka operacyjna (o 19,5\%) i poziom inwestycji (o 16,5\%).

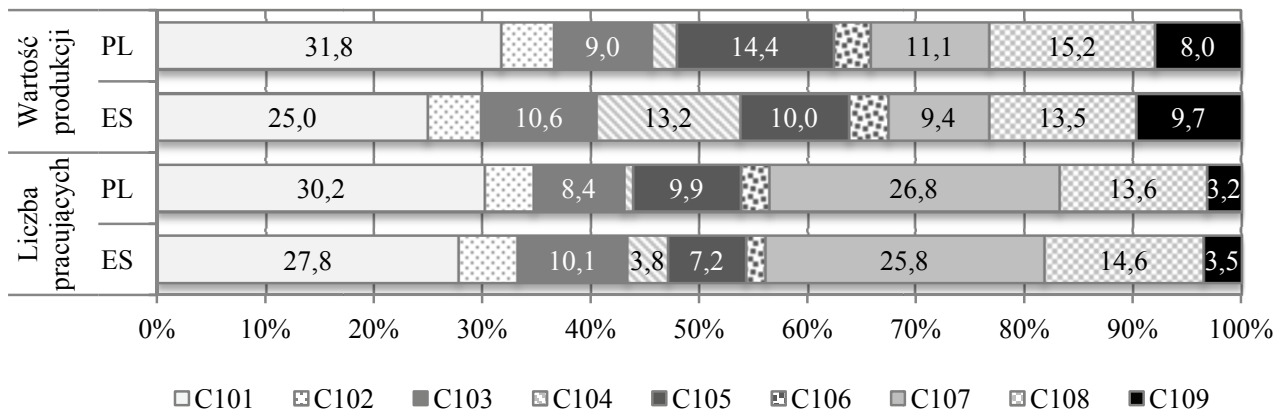

Legenda: C101 - Mięso i wyroby z mięsa, zakonserwowane,

C102 - Ryby, skorupiaki i mięczaki przetworzone i zakonserwowane,

C103 - Owoce i warzywa przetworzone i zakon- serwowane,

C104 - Oleje i tłuszcze zwierzęce i roślinne,

C105 - Wyroby mleczarskie,

C106 - Produkty przemiału zbóż, skrobie i produkty skrobiowe,

C107 - Wyroby piekarskie i mączne,

C108 - Pozostałe artykuły spożywcze

C109 - Gotowe pasze i gotowa karma dla zwierząt

Rys. 4. Struktura wartości produkcji i liczby pracujących w produkcji artykułów żywnościowych (dział C10) według grup wyrobów w Polsce i w Hiszpanii w 2015 roku (w \%)

Fig. 4. Fig. 2. The share of value added (VA) in processing (section $\mathrm{C}$ ) and food industry divisions (C10-C12 divisions) in the value of GDP of Poland and Spain against the EU (in\%)

Źródło: opracowanie własne na podstawie Eurostat.

W Hiszpanii ważną pozycję w produkcji artykułów spożywczych zajmuje grupa C104 - oleje i tłuszcze zwierzęce i roślinne. Wartość produkcji w tej branży sięgająca w 2015 roku 10,6 mld euro stanowiła 13,2\% wartości produkcji w całym dziale 10 (rys. 4). Co ciekawe udział w zatrudnieniu był z kolei jednym z najniższych (3,8\%), co czyni tę branżę bardzo wydajną (964,5 tys. euro obrotu na osobę), a ta wydajność jeszcze wzrosła (rys. 5). Produkcja olejów w ujęciu wartościowym zwiększyła się w badanym okresie najbardziej spośród wszystkich analizowanych grup artykułów żywnościowych produkowanych w Hiszpanii, tj. o $29,2 \%$. Za rozwojem tej branży przemawia również wysoka dynamika nadwyżki operacyjnej (118,5\%) i inwestycji w środki trwałe (131,9\%). W Polsce branża thuszczowa jest relatywnie słabo rozwinięta. Od 2010 roku liczba zakładów wynosząca 159 zwiększyła się o 39,5\%. W porównaniu z Hiszpanią jest ich blisko 10 razy mniej i ponad 10 
razy niższa jest łączna wartość ich produkcji. Polska nie jest w stanie konkurować w produkcji olejów roślinnych z Hiszpanią, choć osiągane w naszym kraju zyski rosną w tempie imponującym (od 2010 roku o 123,4\%).
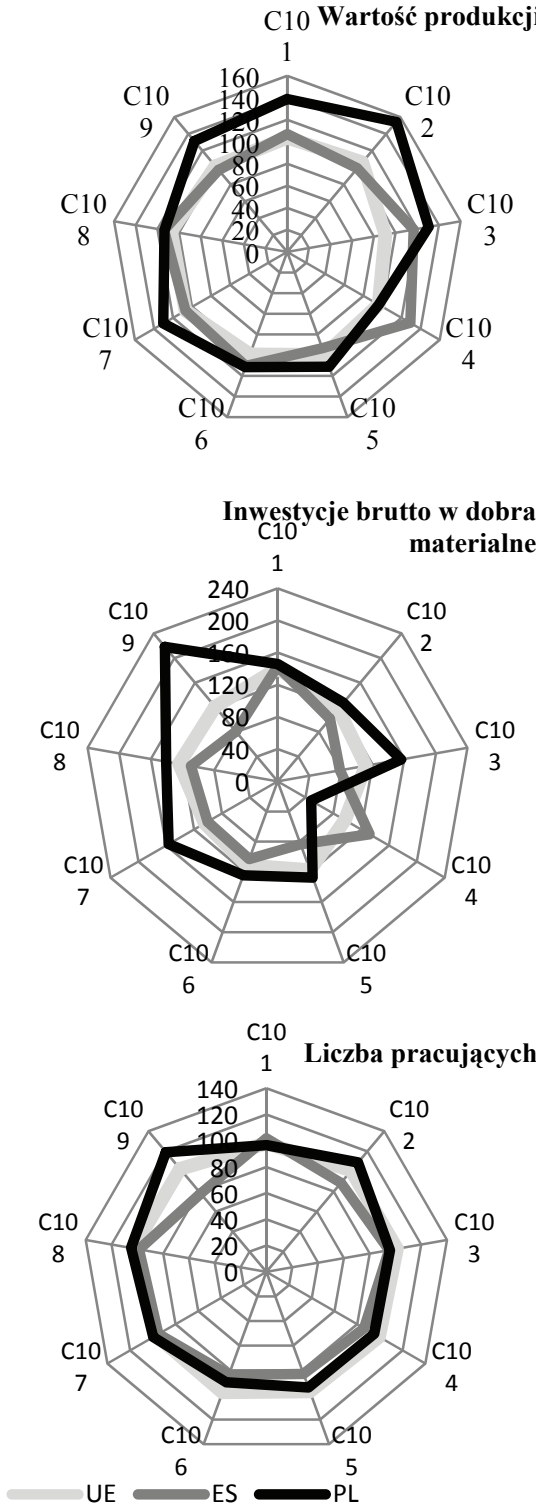

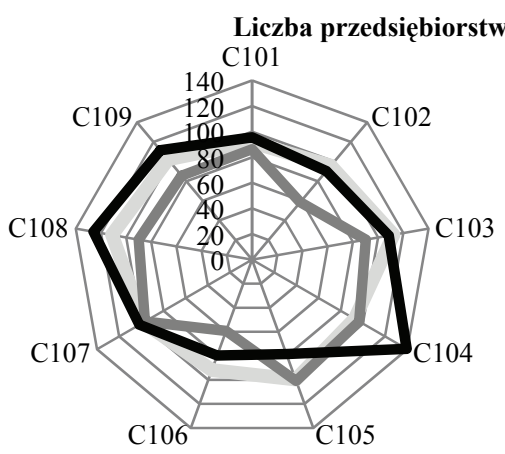

Nadwyżka operacyjna brutto
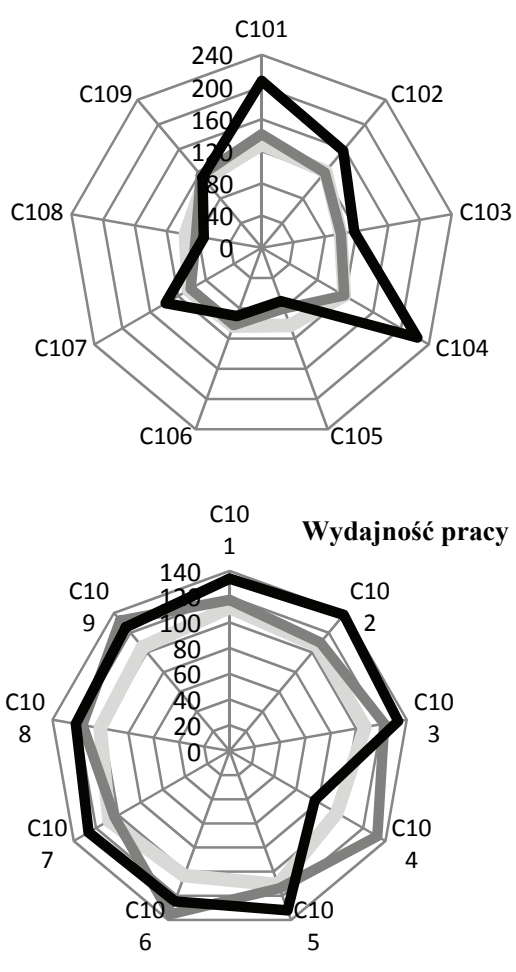

Rys. 5. Dynamika wybranych czynników rozwoju przedsiębiorstw spożywczych według grup NACE w Polsce, Hiszpanii i UE w 2015 roku $(\%, 2010=100)$

Fig. 5. Dynamics of selected development factors in food industry by NACE groups in Poland, Spain and EU in $2015(\%, 2010=100)$

Źródło: opracowanie własne na podstawie Eurostat / UWAGA: Oznaczenia grup produktów - jak na rys. 4. 
Ważną rolę w produkcji i zatrudnieniu odgrywa w obu krajach przetwórstwo owoców i warzyw (grupa C103). W Polsce udział tej grupy w wartości produkcji działu 10 sięga $9,0 \%$, w Hiszpanii wynosi $10,6 \%$. Zbliżone są udziały w zatrudnieniu (rys. 4). W Polsce działa w tej branży 1086 zakładów, w Hiszpanii o 171 więcej. Ich liczba w naszym kraju wzrosła od 2010 roku o 8,4\%, dla porównania w Hiszpanii zmniejszyła się o 9,8\%. Hiszpańska produkcja przetworzonych owoców i warzyw warta była w 2015 roku 8,5 mld euro i wzrosła w badanym okresie o $16,7 \%$. W Polsce wartość tej produkcji była ponad dwukrotnie niższa, ale wzrosła od 2010 roku o 30,7\%. W Polsce widać dynamiczny rozwój branży owocowo-warzywnej. Inwestycje w ciagu 5 lat analizy zwiększyły się $56,3 \%$, w Hiszpanii zaś były niższe o $21,3 \%$. Niezależnie od tego ich kwota w Polsce wynosząca w 2015 roku 223,3 tys. euro była o 37,2\% niższa niż w Hiszpanii. Do rozwoju omawianej branży w Polsce przyczynił się wzrost eksportu owoców i warzyw przede wszystkim na unijne rynki. W przypadku samych owoców ocenia się, że w ciagu 10 lat przynależności Polski do struktur unijnych, ich eksport w ujęciu wartościowym zwiększył się o $131 \%$, a ilościowo wzrósł o 80\% (Kowalska, 2016).

Ogromne zasoby pracy zaangażowane są $\mathrm{w}$ grupie $\mathrm{C} 107$ - wyroby piekarskie $\mathrm{i}$ mączne. W UE w 2015 roku pracownicy piekarni tworzyli zbiorowość 1,5 mln osób. Z tej liczby $7,0 \%$ stanowili piekarze w Polsce i 5,3\% - w Hiszpanii. Piekarnie w naszym kraju sa większe, gdyż w każdej pracuje średnio 17 osób, w Hiszpanii o połowę mniej. Dane statystyczne wskazują na stagnację tej branży w Hiszpanii i jej rozwój w Polsce. W naszym kraju w analizowanym okresie zwiększyła się: liczba zakładów (o 1,7\%), wartość produkcji (o 30,3\%), nadwyżka operacyjna brutto, czyli zysk z działalności operacyjnej pomniejszony o koszty osobowe (o 37,9\%), kwota inwestycji (aż o 56,5\%) i wydajność pracy (o 26,8\%). Jednakże w przypadku tej ostatniej znów należy zauważyć, że wydajność ta jest o blisko połowę niższa niż w Hiszpanii. Branża piekarnicza ma znaczenie lokalne i trudno w niej konkurować na globalnym rynku, chyba, że przenosząc lub otwierając nowe zakłady w innych krajach.

Analizując rys. 4 można zauważyć duży udział grupy C108 (pozostałe artykuły spożywcze) w produkcji i zatrudnieniu w obu krajach. Co ciekawsze okazuje się, że ogromne znaczenie w tej grupie artykułów i to zarówno w Polsce, jak i w Hiszpanii ma przemysł cukrowniczy. Jest on ważny nawet w skali wspólnotowej. Polska i Hiszpania charakteryzują się największą w UE liczbą cukrowni. Jest to jednak branża silnie rozdrobniona (Pawlak, 2013).

Kończąc tę część opracowania warto zwrócić również uwagę na przemysł paszowy (grupa C109), który w Polsce dynamicznie się rozwija. Świadczą o tym rosnące wskaźniki dynamiki wszystkich badanych czynników rozwojowych. Liczba zakładów produkujących pasze i karmy dla zwierząt wynosząca w 2015 roku 446 jednostek zwiększyła się w porównaniu z 2010 rokiem o $11,5 \%$. Przybyło również pracowników o $19,1 \%$ i ich liczba sięgnęła 12,5 tys. osób. Wartość produkcji (3,5 mln euro) wzrosła o 31,4\%, inwestycji - o $118,1 \%$. W Hiszpanii ta branża była bardziej rozwinięta, bo tworzyło ją721 zakładów zatrudniających 12,5 tys. osób, w których wartość produkcji wynosiła 7,8 $\mathrm{mln}$ euro. Jednakże produkcja obniżyła się w ciągu 5 lat o $3 \%$, a inwestycje spadły o $19,4 \%$. Jest zatem w tej branży możliwość podjęcia przez Polskę w przyszłości rywalizacji na unijnym rynku, ale powinno się to wiązać z restrukturyzacją zatrudnienia. 


\section{Podsumowanie}

Przemysł spożywczy jest stosunkowo odporny na wahania koniunktury, choć przykład Hiszpanii pokazał, że również w nim daje się odczuć skutki kryzysu gospodarczego. Spowolnienie jego rozwoju $\mathrm{w}$ omówionych branżach $\mathrm{w}$ porównaniu z Polską może wynikać również z innych przesłanek. Polski sektor rolno-spożywczy rozwija się głównie dzięki ożywczym impulsom związanym wciąż z przystapieniem naszego kraju do struktur UE i objęciem go instrumentami WPR. Polski przemysł spożywczy dobrze wykorzystuje te szansę i wciąż inwestuje w zakłady przetwórcze. Ocenia się, że obecnie są one jednymi $\mathrm{z}$ najnowocześniejszych $\mathrm{w}$ Europie. Oprócz tego obserwuje się koncentrację produkcji w większych konkurencyjnych przedsiębiorstwach przetwórczych, zwłaszcza bazujących na surowcach pochodzenia zwierzęcego. Wyniki badań, choć dotyczą tak krótkiego okresu, sugeruja, że Polska może $\mathrm{w}$ bliższej przyszłości konkurować z Hiszpanią $\mathrm{w}$ branży mleczarskiej, która u nas koncentruje się i inwestuje zwiększając jednocześnie wydajność pracy. W dalszej przyszłości, zachowując obecne tempo rozwoju, będzie mogła konkurować również w produkcji pasz i karm dla zwierząt.

Dużo niższa jest, $\mathrm{w}$ porównaniu $\mathrm{z}$ Hiszpanią, wydajność pracy $\mathrm{w}$ polskich przetwórniach. Wynika to z różnic w stosowanych technologiach i w kosztach czynników wytwórczych. Wydaje się jednak, że wydajność pracy, obliczana jako stosunek wartości obrotów do liczby pracujących, nie jest najlepszym miernikiem w porównaniach między państwami o zróżnicowanym poziomie rozwoju gospodarczego. Lepszą miarą byłby wolumen produkcji przypadający na jednego pracującego. Pozwoliłoby to ocenić rzeczywisty wkład pracy, a nie tylko efekt ekonomiczny zależny od cen produkcji.

Porównywanie Polski i Hiszpanii jest dyskusyjne, zważywszy, że są to kraje, które różni przede wszystkim poziom życia mieszkańców, klimat i zasoby kapitału. Wydaje się jednak, że w UE brak państw bardziej zbliżonych pod względem zasobów wytwórczych, takich jak ziemia i praca. Oczywiście Hiszpania, a ściślej jej przemysł spożywczy, ma silniejszą pozycję konkurencyjna, bo większy jest jej potencjał i efektywność gospodarowania, podobnie jak większości państw bogatej piętnastki. Niemniej jednak polski przemysł spożywczy $\mathrm{w}$ niektórych branżach ma szanse konkurować niższymi kosztami wykorzystywanych czynników produkcji, kilkakrotnie mniejszą opłatą za pracę, czy niższymi marżami przetwórczymi. Dzięki nim uzyskuje przewagi kosztowo-cenowe. Przemysł Hiszpanii jest bardziej kapitało- i materiałochłonny. Wytwarzanie tam jest dużo droższe niż w Polsce. Hiszpania należy do grupy państw charakteryzujących się wysoką wydajnością pracy i jednym $\mathrm{z}$ najwyższych $\mathrm{w}$ UE poziomem uzbrojenia siły roboczej w rzeczowe środki trwałe. Natomiast Polska należy do tych państw europejskich, które cechuje bardzo niska w skali UE wydajności pracy i kapitału oraz słabe wyposażenie pracy w techniczne środki produkcji.

\section{Literatura}

Eurostat. Pobrane 25 maja 2017 z: http://ec.europa.eu/eurostat/data/database

FAOSTAT. Pobrane 1 czerwca 2017 z: http://www.fao.org/faostat/en/\#data/MK

Fierla, I. (red.). (2011). Geografia ekonomiczna Unii Europejskiej. Warszawa: Polskie Wydawnictwo Ekonomiczne, s. 195. 
Global Built Asset Wealth Index (2015). Amsterdam: Arcadis. Pobrane 4 czerwca 2017 z: https://www.arcadis. com/media/8/1/D/\%7B81DC63EB-831F-41F3-BB8E-542031D8E3A6\%7D9385_Global\%20Built\% 20Asset\%20Wealth\%20Index\%202015\%20UPDATED\%20WEB.pdf

Kołodko, G. (2008). Wędrujący świat. Warszawa: Prószyński i S-ka.

Kowalska, A. (2016). Międzynarodowa konkurencyjność polskiego sektora owocowego po przystapieniu do Unii Europejskiej. ZN SGGW Problemy Rolnictwa Światowego 16(31), z. 2, 176-185.

Mroczek, R. (red.). (2015). Przemiany strukturalne przemysłu spożywczego w Polsce i UE na tle wybranych elementów otoczenia zewnętrznego. Warszawa: Instytut Ekonomiki Rolnictwa i Gospodarki Żywnościowej - PIB.

Mroczek, R.(red.).(2014). Polish food industry in 2008-2013. Publikacje Programu Wieloletniego 2011-2014, 117.1. Warszawa: Instytut Ekonomiki Rolnictwa i Gospodarki Żywnościowej - PIB.

NACE Rev.2. Statistical classification of economic activites in the European Community (2008). Luxembourg: Office for Official Publications of the European Communities.

Pawlak, K. (2013). Międzynarodowa zdolność konkurencyjna sektora rolno-spożywczego krajów Unii Europejskiej. Poznań: Uniwersytet Przyrodniczy w Poznaniu.

Piecuch, J., (2017). Regiony Grecji, Hiszpanii, Irlandii i Portugalii w dobie kryzysu z perspektywy zmian struktury produkcji i zatrudnienia. Warszawa: Difin.

Poczta, W., Beba, P. (2014). Rola przemysłu spożywczego w gospodarkach krajów UE. ZN SGGW Problemy Rolnictwa Światowego, 14(29), z. 3, 158-167.

Promoting an EU Industrial Policy for Food and Drink. Competitiveness Report (2014). Brussels: Food Drink Europe. Pobrane 4 czerwca 2017 z: http://www.fooddrinkeurope.eu/uploads/publications_documents/ Promoting_an_EU_industrial_policy_for_food_and_drink.pdf

Rakowski, W. (2017). Hiszpania - Polska. Studium poznawcze rozwoju gospodarczego. Warszawa: CeDeWu.

Szwacka-Mokrzycka, J. (2009). Przemiany na rynku żywności po przystapieniu Polski do Unii Europejskiej. Ekonomika i Organizacja Gospodarki Żywnościowej 79, 63-74.

Szwacka-Mokrzycka, J. (2015). Zachowania przedsiębiorstw przemysłu spożywczego w Polsce w okresie kryzysowym W: A. Czyżewski, B. Klepacki (red.) Problemy rozwoju rolnictwa i gospodarki żywnościowej w pierwszej dekadzie członkostwa Polski w Unii Europejskiej (s. 526-534). Warszawa: Polskie Towarzystwo Ekonomiczne.

Tarnowska, A. (2014). Konkurencyjność podażowa polskiego sektora warzywniczego w Unii Europejskiej. Ekonomia XXI wieku, 3(3), 23-34.

Urban, R., Szczepaniak, I., Mroczek, R. (2010). Polski sektor żywnościowy w pierwszych latach członkostwa (synteza). Warszawa: Instytut Ekonomiki Rolnictwa i Gospodarki Żywnościowej - PIB.

Wrzesińska-Kowal, J., Drabczyk, K. (2014). Food production in Poland, compared to selected European Union Member States. SJ Problems of World Agriculture, 14(4), 205-214.

Wysokińska, Z. (2011). Competitiveness of Polish economy on international markets after accession to European Union W: P. Buła, H. Łyszczarz, A. Mihi Ramirez, J. Teczke (red.) Contemporary Management Challenges in the Transition Period. The Perspectives of Poland and Spain. Cracow: Cracow School of Business, Cracow University of Economics. 